\title{
Chemical evaluation of protein quality of sprouted maize and cowpea
}

\author{
Malomo, Olu. ", Alamu, E. A., Oluwajoba, S. O. \\ College of Food Sciences, Bells University of Technology,Ota, Nigeria
}

Email address:

oludaremalomo1951@yahoo.com(Malomo,Olu.)

\section{To cite this article:}

Malomo, Olu., Alamu, E. A., Oluwajoba, S. O.. Chemical Evaluation of Protein Quality of Sprouted Maize and Cowpea. International Journal of Nutrition and Food Sciences. Vol. 2, No. 5, 2013, pp. 254-260. doi: 10.11648/j.ijnfs.20130205.17

\begin{abstract}
This study was carried out to evaluate protein quality of maize and cowpea grains and the effect of sprouting on this quality. Both grains were germinated for up to 5 days and the protein qualities were evaluated chemically. The use of chemical evaluation is to circumvent the use of animal studies to monitor protein qualities in biological systems which are not perfect measures. The chemical parameters employed were chemical score, essential amino acid index (EAAI), biological value and protein requirement index. The result showed no appreciable change in the parameters tested after germination except for consistent amino acid lysine being limiting as the germination time progresses. This study had shown that contrary to expectations of improvement in protein quality during germination, there was no significant changes even at 5\% probability level.
\end{abstract}

Keywords: Germination, Protein Evaluation, Amino Acids, In-Vitro Digestibility, Chemical Score, Biological Value

\section{Introduction}

Crude protein has been shown to increase as a result of germination by Kylen and McCready (1975) and Fordham et al. (1975), while on the other hand Hsu et al. (1980) and Kumar Venkataraman (1975) reported a decrease in crude protein as a result of germination. Many of the reports to data have furnished contradictory data on the changes in the protein content of germinated legume seeds. However, they all agreed that germination improves the nutritive quality of the legume foods.

The amino acid profile of legume protein changes significantly in the early stages of germination with the breakdown first of high molecular weight fractions and later low-molecular-weight components (Koller et al., 1962; Juo and Stozky, 1970). The amino acids and peptides are translocated tot eh embryonic axis (Altschul et al., 1966). Chen and Thacker (1978) showed that, after 5 days of germination, there was a slight increase in total nitrogen and a slight decrease in protein nitrogen and a marked increase in both total non-protein nitrogen and free-amino acid nitrogen, when compared on a dry weight basis.

Chen and Thacker (1978) and Hsu et al (1980) found the greatest increase to be in glutamic and aspartic acids, while the quantities of all but the sulphur-containing essential amino acids were present in significantly $(p \leq 0.05)$ greater amounts in the sprouts than in the ungerminated seeds (Palmer et al., 1973; Hamilton and Vanderstoep 1979).

Although some studies have shown that the nutritive value of legume protein improves after germination (Everson et al., 1944; Desikachar and De, 1950), studies by Cunningham et al. (1978) and Bau and Derby, (1979) have shown little changes in essential amino acid content during germination. Harrison (1980) also found that the relative distribution of the essential amino acids in the sprouts was not significantly different from that in the seeds, and was not affected by rinsing with different nitrogen-containing solutions during germination. Palmer (1973) and Hamilton and Vanderstoep (1979) reported the sulphur containing amino acids to be first-limiting after germination of the seeds. Hsu et al. (1980) also reported that germination had little effect on the amino acid composition of peas, lentils and faba beans after a 4 day germination.

On the other hand, studies carried out on protein digestibility of germinated legumes by Subbulakshmi et al. (1976) showed a progressive increase in the in-vitro digestibility of horse gram and moth bean proteins after 72 hour germination. At 72 hour germination, moth bean proteins showed an increase $(25 \%)$ in digestibility compared to horse gram (7\%). Khan and Ghafoor (1978) also noticed that the true digestibility of raw mash beans (Phaseolous mungo) were significantly increased when germinated. 
Several other authors have also reported improvement in the protein digestibility after germination (Vankataraman et al., 1976; Everson et al., 1944; Deskachar and De, 1950).

\section{In-Vitro Digestibility}

Chemical score and amino acid index procedures, widely used for evaluating the protein quality of foodstuffs, have been earlier reviewed. Although these procedures are rapid, and in many cases accurate; however, no allowance was made for variations in digestibility and availability of the amino acids. Various methods have been proposed for the in-vitro evaluation of digestibility.

The enzyme system developed by Sheffner et al. (1956) involved determining the essential amino acids released by in-vitro pepsin digestion and those in the remainder of the protein to calculate a "pepsin-digest residue (PDR) amino acid index.

Saunders et al. (1973), in their in-vitro digestibility of protein studies using pepsin, pepsin-pancreatin and pepsin trypsin methods, found that values obtained with either system involving pepsin showed a high degree of correlation with protein digestibility values obtained in rat feeding trails.

Hsu et al. (1977) developed a rapid multi-enzyme technique for estimating protein digestibility. The multienzyme system consisted of trypsin, chymotrypsin and peptidase. They found that the $\mathrm{pH}$ of a protein in suspension immediately after digestion for 10 minutes with the multi-enzyme solution was highly correlated with the in-vivo apparent digestibility in rats. Regression analyses of 23 samples tested by these workers showed that the correlation coefficient between $\mathrm{pH}$ at 10 minutes and invivo apparent digestibility was 0.90 with a standard error estimate of 2.23. The regression equation obtained was $\mathrm{Y}=$ $210.464-18.103 \mathrm{X}$, where $\mathrm{x}$ was the $\mathrm{pH}$ of protein suspension immediately after 10 minutes digestion with the multi-enzyme solution. They claimed that the most significant advantage of this in-vitro method for prediction apparent protein digestibility over others was that it would be completed within one hour and with a high degree of sensitivity. They also claimed that the method could detect the effects of trypsin inhibitor, chlorogenic acid and heat treatment on protein digestibility. Although strong buffer salts may affect the measurement of protein digestibility, the buffering effects found in general food proteins and product tested did not create any problem with this procedure.

Walker (1981) found a high correlation $(r=+089)$ between in-vitro digestibility using the Saunders et al. (1973) method, and available lysine by dye-binding with 7 various leaf protein concentrates. The protein digestibility of Saunders et al. (1973) was used in the present study, because of its high correlation with bio-assay methods and other chemical methods of investigating protein quality, as reported by Walker (1981).

\section{Materials and Methods}

\subsection{Chemical Evaluation of Protein Quality}

\subsubsection{Chemical Score}

The chemical score was estimated by the two methods of calculating chemical score recommend by FAO (1970). The methods are as follows:

Method 1: The content of each essential amino acid in the food protein $(\mathrm{Ax})$ is expressed first as the ratio of essential amino acids (Ex) in the food. These ratios are then expressed as a percentage of the standard ratios of each amino acid in whole egg (Ae) to the total essential amino acids of egg (Ee). The lowest of all these percentages is the chemical score, expressed as or A/E

Method 2: The content of each essential amino acid in the food protein (Ax) is expressed as a percentage of the content of the same amino acid in the same quantity of whole egg (Ae). The amino acid showing the lowest percentage is the chemical score, expressed as $\mathrm{Ax} / \mathrm{Ae}$ or $\mathrm{A} / \mathrm{T}$.

\subsubsection{Essential Amino Acid Index (EAAi)}

The essential amino acid index (EAAI) was estimated according to the method of Oser (1959). This estimation is based on the geometric mean of the ratio of the essential amino acids in a protein relative to their respective amounts in whole egg protein (eg see appendix Table).

\subsubsection{Biological Value}

The biological value of the experimental food materials was calculated from EAAI using Oser's (1959) method as:

Biological value $=1.09($ EAAI $)-11.7 \mathrm{~S}$

\subsubsection{Requirement Index}

The requirement index was estimated according to the method of Rao et al. (1964). It is the geometric mean of the percentage of minimal requirements of the essential amino acids. This method was modified using FAO (1970) minimal requirement for man instead of rat as recommended by Rao et al. (1964). The systematic calculation procedure is shown in appendix Table below.

\subsubsection{Determination of the in Vitro Digestibility of Protein}

The method used in this study was based on that of Saunders et al. (1973), details of which are described below.

One gram of defatted sample was weighed into a $50 \mathrm{ml}$ screw-capped polypropylene centrifuge tube (Du Pont) and suspended in $20 \mathrm{ml}$ of $0.1 \mathrm{~m} \mathrm{HCL}$ and mixed with freshly prepared $50 \mathrm{mg}$ of pepsin in $1 \mathrm{ml} \mathrm{HCL}$. The mixture was gently shaken at $370 \mathrm{C}$ for 48 hours, then centrifuged for 5 min at $20,000 \mathrm{~g}$.

After removal of the supernatant, the solids were resuspended in $20 \mathrm{ml}$ of $0.1 \mathrm{M}$ sodium phosphate buffer, $\mathrm{pH}$ $8.0\left(84 \mathrm{ml} \quad 0.2 \mathrm{~m} \mathrm{Na} \mathrm{Na}_{2} \mathrm{HPO}_{4} .12 \mathrm{H}_{2} \mathrm{O}\right.$ plus $16 \mathrm{ml} \quad 0.2 \mathrm{~m}$ $\mathrm{NaH}_{2} \mathrm{PO}_{4}$ made up to $200 \mathrm{ml}$ with distilled water), and treated with fresh $5 \mathrm{mg}$ of trypsin (Type II, Sigma Chemical Co.). The mixture was gently shaken at $370 \mathrm{C}$ for 16 hours. 
The solid were finally separated by centrifuging at 20,000 x $\mathrm{g}$ for $5 \mathrm{~min}$ and washed once with $30 \mathrm{ml}$ distilled water. The solids were collected on a Whatman No. 541 filter paper and analysed for nitrogen as described in section 3.3.1.

\subsection{Calculation}

The result was calculated as follows:

Protein digestibility $(\%)=\mathrm{N}$ in sample $-\mathrm{N}$ in undigested residue $\mathrm{x} 100$

Nitrogen in sample

\subsubsection{Determination of the Calorific Value of Test Samples}

The calorific value of test samples were determine using a Gallenkamp ballistic (model CBB-330-01). The operating procedure of the instrument manual was used as reported below.

\subsubsection{Sample Preparation}

About $2 \mathrm{~g}$ of corn sample and $0.5 \mathrm{~g}$ in the case of cowpea were weighed of the crucible and content was noticed. The sample was pressed gently after weighing to form it into a smooth and compact material suitable for combustion. The sample was reweighed to obtain an accurate weight. The sample was then dried at $50^{\circ} \mathrm{C}$ for 16 hours. It was cooled after drying in a desiccators and then weighed, the drying was to provide a completely dry sample.

\subsubsection{Operational Procedure}

The dried sample was carefully placed into the calorimeter metal crucible. This was placed on the pillar in the bomb, a standard length of $5 \mathrm{~cm}$ of sewing cotton was fitted to the firing wire and its free end was dipped into the sample. The bomb body was then fitted, the thermocouple inserted, and the bomb charged to a pressure of 25 atmospheres. The galvanometer zero was adjusted and the firing button was pressed afterwards. About 5 unit increase in the readings of the pressure gauge and the galvanometer showed that the firing was successful, and after about a second the peak reading was attained. This peak reading was recorded as the galvanometer deflection. The gas pressure was then released and the bomb body was removed and cooled in water, in preparation for the next test.

The observed deflection was corrected for the heat generated by the firing current and the combustion of the cotton thread. The correction, which was found to be constant from test, was determined by the above procedure, but without any sample in the crucible.

\subsection{Calculations}

The calculation of the calorific value of the test samples was carried out as follows:

i. Determination of Calibration Constant

Weight of benozoic acid $=0.456 \mathrm{~g}$

Heat released from benzoic acid $=6.32 \mathrm{kcal} / \mathrm{g}$
Heat released from $0.456 \mathrm{~g}$ benzoic acid $=6.32 \mathrm{x}$ $0.456 \mathrm{kcal}$

$=2.86 \mathrm{kcal}$

Galvanometer deflection of thread without sample $=0.3$

Galvanometer deflection of thread + benzoic acid $=$ 6.55

Calibration constant $=2.86=0.4608 \mathrm{kcal} /$ Deflection

$(6.55-0.3)$

ii Heat released from Individual Samples

Heat released from sample $=\mathrm{a} \times 0.4608=$ Gross energy

b

where $\mathrm{a}=$ Deflection from galvanometer when

sample was bombed

$\mathrm{b}=$ weight of sample, $\mathrm{g}$

iii Metabolizable Energy

The metabolizatble energy was calculated according to Millar and Payne (1959).

Their calculation is based on two factors, the first (0.95) converts the gross energy (GE) from foodstuffs into digestible energy. The second factor is based on the fact that $1.25 \mathrm{kcal}$ was the urinary loss fromlg of protein broken down in the body. This was found to be equivalent to $7.8 \mathrm{kcal} / \mathrm{g}$ absorbed nitrogen and approximately 7.5 $\mathrm{kcal} / \mathrm{g}$ for total nitrogen.

Hence, metabolizable energy $=(\mathrm{GE} / \mathrm{g} \times 0.95)-(\mathrm{N} \% \times$ $0.75)$.

\subsection{Changes in in-Vitro Protein Digestibility of Maize and Cowpea during Sprouting}

Changes in the in-vitro protein digestibility of maize and cowpea during sprouting are shown in Tables 3 and 4, respectively.

Both raw and sprouted maize grains show high digestibility, but digestibility increased with the length of the sprouting period (correlation, $\mathrm{r}=+0.95$ ).

Digestibility of raw cowpea protein is low $(65 \%)$, but was rapidly increased by sprouting $(90 \%$ after 2 days of sprouting). Protein digestibility of cowpea was also found to be highly correlated with sprouting period $(\mathrm{r}=+0.877)$. However, losses in total dry matter of eh sprouted grains were not considered in the digestibility calculation; when considered it alters the image of the digestibility especially for sprouted maize. This is discussed further in section 5.5 .1

\subsection{Changes in in-Vitro Digestibility of Maize and Cowpea during Sprouting}

\subsubsection{Changes in in-Vitro Digestibility of Maize during Sprouting}

The in-vitro digestibility of maize, although high $(84.5 \%)$, was further increased by germination in proportion to the length of the germination period (Table 3 ). The length of sprouting period and the proportional increase in digestibility was also highly correlated with the 
percentage available of total lysine of sprouted maize $(\mathrm{r}=+$ $0.97)$.

\section{Results}

\subsection{Chemical Evaluation of Protein Quality}

The chemical score of 2-day maize sprouts had decreased, but increased afterwards up to the fifth day. In the early stages of maize sprouting, isoleucine and lysine were the most limiting (Table 1). However, lysine remained limiting at later stages to be joined by valine at the fifth day of sprouting. The essential amino acid index (EAAI), requirement index and biological values follow the same pattern of changes all through the sprouting period. These parameter have been found to be lower in value in the sprouted maize samples than in the raw maize sample as a whole.

Table 2 shows results of chemical score, limiting amino acid, essential amino acid index and in the protein biological values of raw and sprouted cowpea. The chemical scores, similar to those obtained for maize (Table 1), decreased continuously up to the third day as the sprouting progressed. Although, at day five there was an improvement, the scores were still lower than those in the raw cowpea. Methionine remained the most limiting amino acid throughout the sprouting process. The essential amino acid index and the biological values increased with 2-day sprouts, but then decreased. The requirement index was observed to decrease with the germination of the grain.

The 'dip' in the nutritional value of sprouted maize and cowpea observed in Tables 1 and 2, respectively, is evident from their essential amino acids composition.

\subsection{Changes in in-Vitro Digestibility of Maize and Cowpea during Sprouting}

\subsubsection{Changes in in-Vitro Digestibility of Maize during Sprouting}

The in-vitro digestibility of maize, although high $(84.5 \%)$, was further increased by germination in proportion to the length of the germination period (Table $21)$. The length of sprouting period and the proportional increase in digestibility was also highly correlated with the percentage available of total lysine of sprouted maize $(r=+$ $0.97)$.

\section{Conclusion}

\subsection{Sprouting Effect on Chemical Score, Limiting Amino Acid, Essential Amino Acid Index and Calculated Biological Value of Maize and Cowpea Grains}

The nutritional value of protein is limited by the essential amino acid present in the lowest amount (FAO/WHO, 1965). The chemical scores of both sprouted maize and cowpea decreased at early stages of germination and increased again towards the later stage.
The increase of chemical score at the later stage of the seeds germination still left chemical score lower than that in the raw unsprouted seeds. At the early stage of maize germination, isoleucine and lysine were both limiting. However, lysine and valine became limiting at a later stage, while in cowpea, methionine remained the most limiting essential amino acid during the germination period.

The essential amino acid index (EAAI), requirement index (RI) and biological values (BV) of maize decreased at the early stages of sprouting and increased towards the later stages While cowpea exhibited little or no difference between the essential amino acid index and the biological values of the raw cowpea grains and those of the early stages of sprouting, these values decreased at the later stages. The requirement index decreased with increasing sprouting period, but this reduction was small.

It is concluded that from the data (Tables 1and 2) that raw maize contains protein with higher nutritive value than sprouted maize, while 2-day sprouts of cowpeas contain proteins with a higher nutritive value than the raw and the other sprouts (i.e 3 and 5-day sprouts).

According to Eggum (1968), chemical assay methods are of limited value for analysis of protein quality, because digestibility and biological availability are overlooked. However, net protein use and biological value are unsatisfactory methods for assessing the protein value of grains, such as maize, that are low in lysine (Said and Hegsted, 1969 and 1970). Thus, the methods used here are quite useful supplements to the biological methods and are particularly valuable in predicting amino acid deficiency.

From this investigation it appeared that, during grain germination, changes occurred in the synthesis of various nitrogen fractions. The increase or decrease in the content of certain amino acids might be due largely to changes in the proportions of the protein fractions during grain germination. The decline or increases in chemical scores, essential amino acid indices, requirement indices and calculated biological values were due to decreased or increased values of essential amino acids from which these values were calculated.

Although some studies have shown that the nutritive values of legumes and cereals improved after germination (Everson et al., 1944; Wang and Fields, 1978; Hammad and Fields, 1979), Cunningham et al. (1978) and Bau and Derby (1979) reported little or no changes in the nutritive values of cottonseed and soy bean proteins after germination.

With in vitro digestibility;

\subsection{Effect of Sprouting on Digestibility Energy, Metabolizable Energy, Protein Content and Protein Metabolizable Energy Ratipo of Maize and Cowpea}

Sprouting had little or no effect on either the protein or energy content of maize. Consequently, there was no significant changes $(\mathrm{p} \geq 0.05)$ in the protein-metabolizable energy ratio of the maize grain on sprouting. The proteinmetaboilizable energy ratio obtained for maize was very 
low (0.022), whereas a net protein-calorie ratio of 0.030 is recommended for high quality protein foods, when energy needs of adults are met (FAO/WHO, 1973).

On the other hand, cowpea, both raw and sprouted satisfied this requirement (0.062). The only changes observed took place during the third and fifth day of sprouting where only very minimal changes in the metabolizable energy resulted from germination.

\subsection{Sprouting Effect on the Chemical Score, Limiting Amino Acid, Essential Amino Acid Index and Calculated Biological Value of Maize Grains (Zea Mays)}

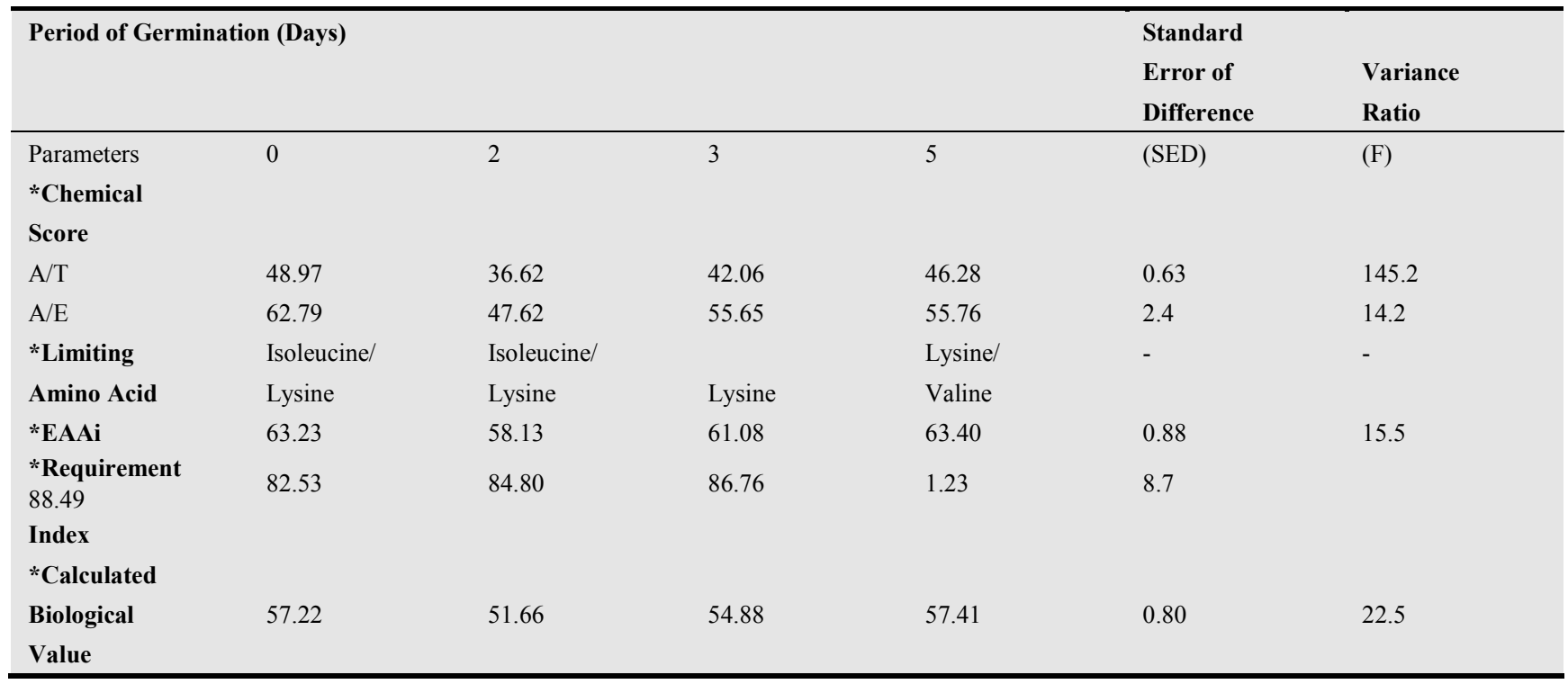

5.4. Effect of Sprouting on the Chemical Score, Limiting Amino Acid, Essential Amino Acid, Essential Amino Acid Index and Calculated Biological Value of Cowpea (Vigna Unguiculata)

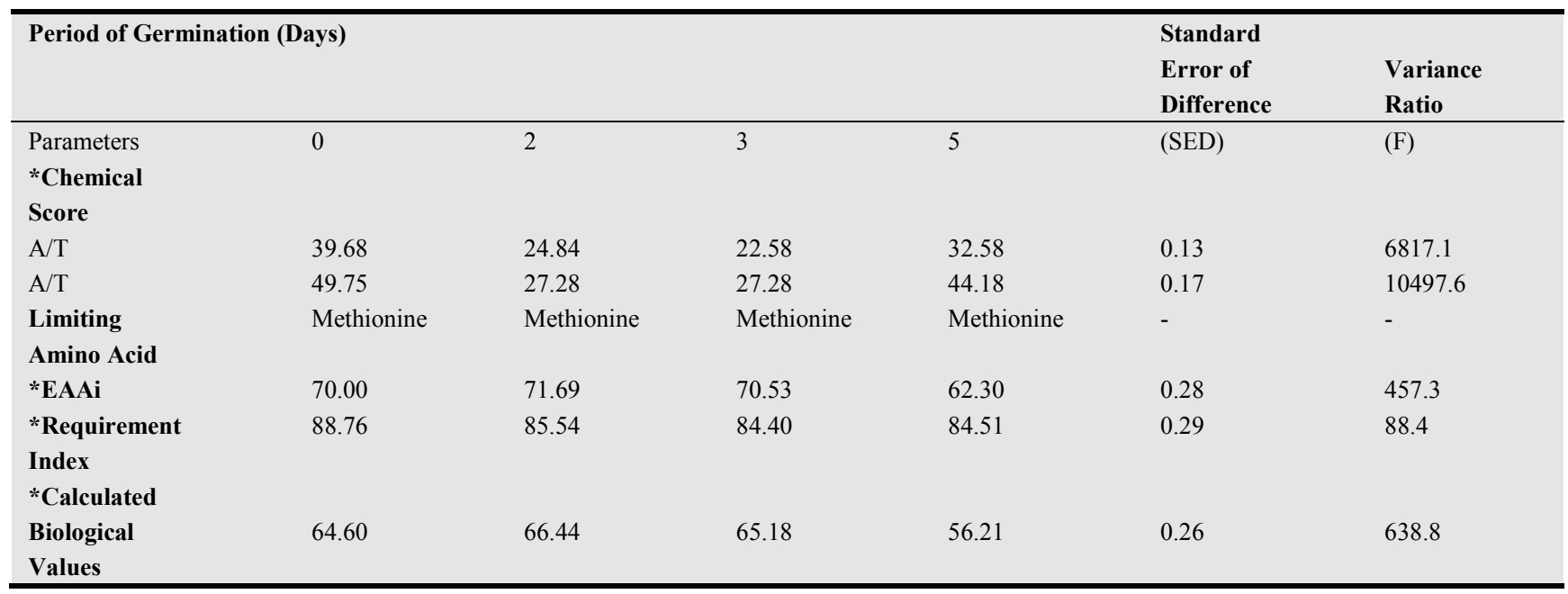

Table 3. Changes in in-vitro digestibility of maize during sprouting

\begin{tabular}{|c|c|c|c|c|c|c|}
\hline & \multicolumn{4}{|c|}{ Germination Period (Days) } & \multirow{2}{*}{$\begin{array}{l}\text { Standard } \\
\text { Error of Difference } \\
\text { (Sed) }\end{array}$} & \multirow{2}{*}{$\begin{array}{l}\text { Variance } \\
\text { Ratio } \\
\text { (F) }\end{array}$} \\
\hline & $\mathbf{0}$ & 2 & 3 & 5 & & \\
\hline \% Digestibility & 84.445 & 89.873 & 92.203 & 94.413 & 0.025 & 6303.54 \\
\hline
\end{tabular}

Table 4. Changes in in-vitro digestibility of cowpea during sprouting

\begin{tabular}{|c|c|c|c|c|c|c|}
\hline & \multicolumn{4}{|c|}{ Germination Period (Days) } & \multirow{2}{*}{$\begin{array}{l}\text { Standard } \\
\text { Error of Difference } \\
\text { (Sed) }\end{array}$} & \multirow{2}{*}{$\begin{array}{l}\text { Variance } \\
\text { Ratio } \\
\text { (F) }\end{array}$} \\
\hline & $\mathbf{0}$ & 2 & 3 & 5 & & \\
\hline$\%$ Digestibility & 65.480 & 90.007 & 91.647 & 94.569 & 0.0813 & 6842.48 \\
\hline
\end{tabular}




\section{References}

[1] AltSCHUL, A. M., YATSU L. Y., ORY R. L. and ENGLEMAN E. M. (1966). Seed

[2] Proteins. Ann. Rev. physiol. 17: 113.

[3] BAU, H. M. and DERBY G. (1979). Germinated soy protein products: chemical

[4] and nutritional Evaluation. J. Am. Oil chem.. Sci. 56: 160.

[5] CHEN, L. H. and THACKER R. (1978). Germination and nitrogenous constituents of

[6] pea seeds (Pisum sativum L.) J. Food Sci. 43. 1884.

[7] CUNNINGGHAM, S. D., CARTER C. M. and MATTIL K. F. (1978). Effect of germination

[8] on cotton seed protein. J. Food Sci. 43: 102.

[9] DESIKACHAR, H. S. R. and DE S. S. (1950). The trypsin inhibitor and availability of

[10] cystine and methionine in raw and germinated soya beans. Biochem Biophys. Acta. 5: 285.

[11] EGGUM, B. D. (1968). Evaluation of protein quality and the development of

[12] screening techniques. Panel on new approach

[13] EVERSON, G. J., STEENBOCK M. and CEDERQUIST M. (1944). The effect of germination

[14] on the age of maturity, and variety upon the nutritive value of soybean protein. J. Nutr. 27: 225.

[15] FAO/WHO (1965). Expert group Joint report : WHO protein requirement. WHO

[16] Technical rept. Ser. No. 301. WHO, Geneva.

[17] FORDHAM, J. R., WELLS C. E. and CHEN L. H. (1975). Sprouting of seeds and

[18] nutrients composition of seeds and sprouts.

[19] FRENCH, D. (1954). The raffinose family of oligosaccharides. Adv. Carbohyd. Chem.. 9: 149.

[20] HAMAD, A. M. and FIELDS M. L. (1970). Evaluation of the protein quality and

[21] available lysine of germinated and fermented cereals. 44: 456.

[22] HAMILTON, M. J. and VANDERSTOEP J. (1979). Germination and nutrient composition

[23] of alfalfa seeds. J. Food Sci. 44: 443.

[24] HARRISON, J. E. (1980). The effects of various growth conditions on the

[25] nutritive composition of alfalfa sprouts.

[26] HSU, D. LEUNG H. K., FINNEY P. L. and MORAD M. M. (1980). Effect of germination
[27] on nutritive value and baking properties of dry peas, lentils and faba beans. J. Food Sci. 45: 87.

[28] JUO, P. and STOTZKY G. (1970). Changes in protein spectra of beans seed

[29] during germination. Can. J. Bot. 48:1347.

[30] KHAN, M. A. and GHAFOOR A. (1978). The effect of soaking, germination and cooking

[31] on the protein quality of mash beans (Phaseoulus mungo). J. Sci. Food Agric. 29: 461.

[32] KOLLER, D., MAYER A. M., POLJAKOFF-MAYER A. and KLEIN S. (1962). Seed

[33] germination. Ann. Rev. Plant. Physiol. 13: 437.

[34] KUMAR, G. K. and VENKATORAM L. V. (1975). Changes in reserve proteins of

[35] cowpea, chickpea and green-gram during germination: Physico chemical studies. J. Food Sci. and Technol. 12: 292.

[36] KYLEN, A. M. and MCCREEDY R. M. (1975). Nutrients in seeds and sprouts of

[37] alfalfa, lentils, mung beans and soy beans . J. Food Sci. 40: 1008 .

[38] MILLER, D. S. and PAYNE P. R. (1959). A ballistic bomb caloricmeter. Brit. J. Nutr.

[39] 13:501.

[40] OSER, B. L. (1959). An integrated essential amino acid index for predicting the

[41] biological value of proteins. In: Protein and amino acid nutrition (ed. A. A. Albanese). and legumes. Nutr. Report Int. 11:313.

[42] PALMER, R., McINTOSH A. and PUSZTAI A. (1973). The nutritional evaluation of

[43] kidney beans (Phaseolus vulgaris). The effect of nutritional value of sed germination and changes in trypsin nhibitor content.J. Sci. Food Agric. 24: 937.

[44] SAID, A. K. and HEGSTED D. M. (1969). Evaluation of dietary protein quality in

[45] adult rats. J. Nutr. 99: 474

[46] SAUNDERS, R. M., CONNOR M. A., BOOTH A. I. N., BRICKOFF E. M. and KOHLER G. O.

[47] (1973). Measurement of digestibility of alfalfa protein concentrates by vivo and vitro methods. J. Nutr. 103: 530 .

[48] SHEFFENER, A. L., ECKFELDT G. A. and SPECTOR H. (1956). The pepsin digest

[49] residue (PDR) amino acid index of net protein utilization. J. Nutr. 60: 105.

[50] SUBBULAKSHMI, G., KUMAR G. K. and VENKATARAMAN L. V. (1976). Effect

[51] of germination on the carbohydrates, proteins, trypsin inhibitor, amylase inhibitor and haemaglitinin in horse gram 
and moth bean. Nutr. Report Int. 13: 19.

[52] VENKATARAMAN, L. V., JAYA T. V. and KRISHNAMARTHY K. S. (1976). Effect

[53] of germination on the biological value, digestibility coefficient and net protein utilization of some legume proteins. Nutr. Dietet. 15: 9 .

[54] WALKER, A. F. (1981). The application of in vitro methods to the estimation of
[55] protein quality of leaf protein concentrates. $\mathrm{PhD}$ Thesis, University of Reading, Reading, England.

[56] WANG, Y. D. and FIELDS M. L. (1978). Germination of corn and sorghum in the home to

[57] improve nutritional value. J. Food. Sci. 43: 1113. 